\title{
Economic Impact of McNenny State Fish Hatchery, Spearfish, South Dakota, USA
}

\author{
Michael E. Barnes*, Timothy Palmer \\ McNenny State Fish Hatchery, South Dakota Game, Fish and Parks, Spearfish, USA \\ Email: ^mike.barnes@state.sd.us
}

How to cite this paper: Barnes, M.E. and Palmer, T. (2019) Economic Impact of McNenny State Fish Hatchery, Spearfish, South Dakota, USA. Modern Economy, 10, 1581-1588.

https://doi.org/10.4236/me.2019.106104

Received: May 10, 2019

Accepted: June 25, 2019

Published: June 28, 2019

Copyright (c) 2019 by author(s) and Scientific Research Publishing Inc. This work is licensed under the Creative Commons Attribution International License (CC BY 4.0).

http://creativecommons.org/licenses/by/4.0/

(c) (i) Open Access

\begin{abstract}
McNenny State Fish Hatchery, rural Spearfish, South Dakota, USA produces trout and salmon for stocking into public recreational fishing waters in South Dakota. Hatchery operations at McNenny are funded solely by the sale of hunting and fishing licenses and an excise tax on fishing equipment. This study evaluated the monetary contribution of hatchery expenditures and fish production to the local economy of South Dakota for calendar year 2017. The economic value of the fish raised at McNenny State Fish Hatchery in 2017 was calculated to be $\$ 6,609,576.03$ USD. When added to the estimated McNenny share of angler expenditures in the Black Hills National Forest, the total local monetary impact of McNenny State Fish Hatchery operations and fish stocking was slightly more than $\$ 22$ million. Based on annual hatchery expenditures, McNenny operations generated $\$ 51.68$ of local economic output for every budgetary dollar spent in 2017.
\end{abstract}

\section{Keywords}

Fish Hatchery, Economic Impact, Recreational Fishing

\section{Introduction}

Recreational angling is a very important component of the gross domestic product of the United States [1]. After jogging, it is the second most popular outdoor activity in the country [2]. In 2017, over 49 million Americans representing $17 \%$ of the entire population of the United States took approximately 885 million fishing outings [2]. These anglers generated nearly $\$ 50$ billion (USD) in retail sales, impacting the livelihoods of more than 800,000 people [3].

Fish produced in publicly-owned hatcheries are critical to the creation, maintenance, and improvement of recreational fishing opportunities in the United 
States [4]. For example, in 2016, the United States Fish and Wildlife Service produced and released 135 million adult and juvenile fishes from 66 federal hatcheries into the waters of 44 states [5]. Nearly every state government also owns and operates numerous hatcheries producing fish for recreational angling. Some examples include Colorado, with 19 government freshwater hatcheries producing 90 million fish a year for stocking into public fishing waters

(https://cpw.state.co.us/hatcheries), New York, with 12 hatcheries producing 2.3 million catchable-size trout (http://www.dec.ny.gov/outdoor/7742.html), and Texas, with 3 saltwater and 5 freshwater hatcheries, growing and stocking nearly 40 million fish each year

(https://tpwd.texas.gov/fishboat/fish/management/stocking/). In 2016, the state of Oregon employed 166 individuals at its 32 publically-owned hatcheries, who were responsible for producing nearly 47 million trout and salmon weighing $1,800 \mathrm{t}$ [6]. In total, government hatcheries produced nearly 29,000 $\mathrm{t}$ of fish for recreational purposes in 2013, over half of which was rainbow trout (Oncorhynchus mykiss) [7]. Rainbow trout are one of the most widely stocked fish in North America [8], and are typically produced at a size suitable for immediate harvest [9]. The economic benefits and impacts of hatchery-reared fish, particularly rainbow trout and other salmonid species, stocked into public fishing waters can be considerable [10] [11] [12] [13].

The state of South Dakota owns and operates two hatcheries focused solely on trout and salmon production: Cleghorn Springs State Fish Hatchery in Rapid City and McNenny State Fish Hatchery near Spearfish. No trout or salmon are native to South Dakota [14], and natural reproduction is negligible except for brown trout (Salmo trutta) and brook trout (Salvelinus fontinalis) in selected streams in the Black Hills. Thus, hatchery rearing is essential to recreational fishing for trout and salmon in South Dakota. The stocking of hatchery-reared fish accounts for nearly all of the rainbow trout, and absolutely all of the Chinook salmon (Oncorhynchus tshawytscha), caught by anglers in South Dakota. From July 1, 2017 to June 30, 2018, 417,757 trout and salmon produced at Cleghorn and McNenny State Fish Hatcheries were stocked into public fishing waters in South Dakota [15].

Although economic analyses have been conducted for individual fisheries maintained by hatchery-produced fish [10] [12] and for hatchery systems on the federal level [13], little information on the economic impact of individual hatcheries at the state level is available. As a governmental organization owning and operating fish hatcheries, the South Dakota Department of Game, Fish and Parks has a stewardship obligation with the use of public funding [16], making it important to understand the financial ramifications and economic impacts of hatchery operations. Thus, the objective of this study was to determine to economic impact of McNenny State Fish Hatchery fish production on the local economies of South Dakota, providing the first published estimates of the economic impact of any state-owned fish hatchery in the United States. 
The remainder of this paper is organized with the next section after this introduction describing the methods used for this study. After the methods, Section 3 describes the results, including the overall local economic impact of McNenny State Fish Hatchery and the return on budgetary expenditures in US dollars. Following the results, the final section compares and contrasts the results with those from the few other studies examining the economic impact of other public fish hatcheries, and also discusses the significance of the results.

\section{Methods}

A combination of hatchery expenditure data and stocking data was used to evaluate the local (within South Dakota) economic impact of fish production at McNenny State Fish Hatchery. The economic analysis used actual expenditure data for 2017, removing out-of-state expenditures. Included in the summation of local spending were the wages and benefits paid to permanent and temporary hatchery employees, supplies, fuel, equipment, and other materials purchased from South Dakota vendors, as well as utility costs and services provided by local contractors (Table 1). All of this data was considered local economic output, because spending was put back into South Dakota businesses and directly reinvested into the local economy. Non-local expenditures which were excluded from the analysis included the costs of fish food, computer hardware, and specialized scientific equipment procured from out-of-state vendors. In addition, any money spent on one-time, monetarily-large, construction projects was also excluded.

In addition to direct economic expenditures, all of the fish from the hatchery stocked in 2017 were included in the analysis. As a facility owned and operated by the State of South Dakota, and funded entirely from the sale of fishing licenses and an excise tax on fishing equipment [17], all of the fish produced at McNenny State Fish Hatchery are stocked into public fishing waters within the state of South Dakota. Rainbow trout, brown trout, and Chinook salmon were stocked from McNenny Hatchery in 2017 at locations throughout the state.

Using the values obtained by Johnson and Walsh [10], all of the trout stocked were assigned a base dollar value and adjusted to current Consumer Price Index (CPI) Standards [18] based on what an angler would be willing to pay for each

Table 1. McNenny State Fish Hatchery expenditure categories and amount spent in 2017.

\begin{tabular}{cc}
\hline Expenditure Category & Amount (\$) \\
Salaries & 244,569 \\
Benefits & 77,473 \\
In-state travel & 5200 \\
Service and utilities & 75,560 \\
Supplies & 30,450 \\
Total & 433,252 \\
\hline
\end{tabular}


fish. Because anglers are willing to pay more for larger fish [19], which Whitehead and Aiken [20] estimated at 3.5\% more per $\mathrm{cm}$ increase in trout length greater than $23 \mathrm{~cm}$, the inflated-adjusted base value was increased accordingly for fish at each stocking size.

Unlike the rainbow and brown trout which are stocked into public fishing waters to provide immediate recreation under the assumption that they will be caught relatively quickly [21] [22], Chinook salmon are stocked at a much smaller size and expected to grow for at least two years prior to being caught. For these stockings, the total economic value of the salmon fishery was determined by multiplying the number of angler trips [23] by the average spending per trip [24]. This value was adjusted to current CPI standards and multiplied by the percentage of the total salmon raised and stocked from McNenny hatchery. This value was then divided by the total number of salmon stocked to create a per-fish value for the salmon. In addition to the per fish valuations, the value of the expenditures per day for anglers in the Black Hills National Forest of South Dakota ( $\$ 74.93 /$ day, and a total of 2,984,192 angler days per year) was multiplied by the percent share (66.67\%) of the fish stocked from McNenny of all of the fish stocked in the Black Hills National Forest [25].

The total value of fish stocked by McNenny was calculated by adding the values for each species and size of fish. The share of angler expenditures in the Black Hills attributed to the hatchery was then added to the total value of the fish stocked to produce the total economic impact. The economic impact per dollar spent by the hatchery was then determined by dividing the total economic impact by the annual budgetary expenditures of McNenny.

\section{Results}

The economic value of the fish raised at McNenny State Fish Hatchery was calculated to be $\$ 6,609,576.03$ (Table 2). When added to the estimated McNenny share of angler expenditures in the Black Hills National Forest, the total monetary impact of McNenny State Fish Hatchery operation and fish stocking was slightly more than $\$ 22$ million (Table 3). Based on annual hatchery expenditures, McNenny operations generated $\$ 51.68$ of economic output for every budgetary dollar spent.

Table 2. Number, size, and species of fish stocked from McNenny State Fish Hatchery in 2017, along with base values (USD) per fish and fish size multipliers.

\begin{tabular}{cccccc}
\hline Species & Size $(\mathrm{cm})$ & Number & Multiplier & Base Value $(\$)$ & Total Value $(\$)$ \\
\hline Rainbow trout & 28 & 28,809 & 2.50 & 5.60 & $161,272.78$ \\
Rainbow trout & 31 & 24,809 & 3.75 & 6.85 & $169,892.03$ \\
Rainbow trout & 41 & 25,000 & 8.75 & 11.85 & $296,200.00$ \\
Brown trout & 26 & 12,692 & 1.00 & 4.10 & $52,011.82$ \\
Chinook salmon & 9 & 32,000 & 1.00 & 185.29 & $5,929,200.00$ \\
Total & & 123,310 & & & $6,609,576.63$ \\
\hline
\end{tabular}


Table 3. Economic impact (USD) of McNenny State Fish Hatchery fish production and stocking on local South Dakota, USA, economies, along with the impact per budgetary dollar spent.

\begin{tabular}{cc}
\hline Category & Value $(\$)$ \\
\hline Fish stocked & $6,609,576.63$ \\
Share of Black Hills angler expenditures & $15,780,048.02$ \\
Total economic impact & $22,388,624.65$ \\
Hatchery budgetary expenditures & $433,252.00$ \\
Economic impact/budgetary dollar spent & 51.68 \\
\hline
\end{tabular}

\section{Discussion}

The economic output of $\$ 51.68$ per budget dollar expenditure for McNenny Hatchery is relatively close to the inflation-adjusted (to 2018 USD) economic output of $\$ 47.94$ calculated for hatcheries operated by the US Fish and Wildlife Service [13]. In contrast, economic effects ranging from $\$ 109$ to $\$ 141$ for each hatchery budget spent have been reported from hatcheries producing catchable-sized trout in the more heavily populated southeastern portion of the United States [26]. The economic impact of McNenny Hatchery identified in this study confirms the substantial economic activity generated by the stocking of hatchery-reared trout and salmon for recreational fishing identified across the United States [10] [11] [12] [27].

The local total economic impact of slightly more than $\$ 22$ million by McNenny Hatchery occurred without the expenditure of any South Dakota government general tax revenue [17]. This indicates that the current user-pay model, whereby anglers pay for hatchery operations by purchasing licenses and fishing equipment, is providing substantial benefits to the non-angling public. Direct spending on outdoor recreation and the associated indirect benefits are a substantial component of the economy of South Dakota [28].

The economic impact from McNenny Hatchery operations is likely much greater than that reported in this study. Several large regular expenditures, such as fish food purchases, were excluded from the analysis because the manufacturer was located outside of South Dakota. The impact of one-time, monetarily-large, irregularly-occurring, construction expenditures was also excluded. Lastly, this study did not include the long-term economic impacts of hatchery research and innovation. Although somewhat difficult to quantify [29] [30] [31], the considerable and consistent year-to-year research output at McNenny likely produces substantial long-term economic benefits both within the local economy and well-beyond the borders of South Dakota [32] [33] [34].

This study is the first to determine the economic impact of any publicly-owned fish hatchery in South Dakota, and any state-owed fish hatchery in the United States. This information can be used by administrators while making decisions on future budgeting and expenditures. As an initial effort, the results from this study should be verified by additional information on hatchery economics as 
well as a large survey of anglers to determine more accurate values for willingness-to-pay per fish caught or for increases in fish size.

\section{Acknowledgements}

We thank Jill Voorhees and Nathan Huysman for their review of this manuscript and Robert Hanten for his assistance in obtaining information on the Chinook salmon program.

\section{Conflicts of Interest}

The authors declare no conflicts of interest regarding the publication of this paper.

\section{References}

[1] Bureau of Economic Analysis (BEA) (2018) Outdoor Recreation Satellite Account. https://www.bea.gov/news/2018/outdoor-recreation-satellite-account-updated-stati stics-2012-2016

[2] Outdoor Industry Association (OIA) (2018) Outdoor Participation Report. https://outdoorindustry.org/resource/2018-outdoor-participation-report

[3] U.S. Fish and Wildlife Service and U.S. Census Bureau (USFWS and USCB) (2018) 2016 National Survey of Fishing, Hunting, and Wildlife-Associated Recreation. Publication FHW/16-Nat(RV). https://doi.org/10.3886/ICPSR08201

[4] Jackson, J.R., Boxrucker, J.C. and Willis, D.W. (2004) Trends in Agency Use of Propagated Fishes as a Management Tool in Inland Fisheries. American Fisheries Symposium, 44, 121-138.

[5] U.S. Fish and Wildlife Service (USFWS) (2019) Fish Production. https://www.fws.gov/fisheries/nfhs/fish_production.html

[6] Chilton, G. (2017) Fish Propagation Annual Report for 2016. Fish Division, Oregon Department of Fish and Wildlife, Salem. https://doi.org/10.2172/963065

[7] United States Department of Agriculture (USDA) (2014) 2012 Census of Agriculture. Census of Aquaculture (2013), Volume 3, Part 2, AC-12-SS-2, Washington DC.

https://www.agcensus.usda.gov/Publications/2012/Online_Resources/Aquaculture/ aquacen.pdf

[8] MacCrimmon, H.R. (1971) World Distribution of Rainbow Trout (Salmo gairdneri). Journal of the Fisheries Research Board of Canada, 28, 663-704. https://doi.org/10.1139/f71-098

[9] Kerr, S.J. and Lasenby, T.A. (2000) Rainbow Trout Stocking in Inland Lakes and Streams: An Annotated Bibliography and Literature Review. Fish and Wildlife Branch, Ontario Ministry of Natural Resources, Peterborough.

[10] Johnson, D.M. and Walsh, R.G. (1987) Economic Benefits and Costs of the Fish Stocking Program at Blue Mesa Reservoir, Colorado. Colorado Water Resources Research Institute, Fort Collins.

[11] Caudill, J. (2005) The Economic Effects of Rainbow Trout Stockings by Fish and Wildlife Service Hatcheries in FY 2004. U.S. Fish and Wildlife Service, Division of Economics, Arlington.

[12] Caudill, J. (2007) The Economic Impacts of Trout Stocking on Tailwaters in the 
Southeast Aquatic Resources Partership (SARP). U.S. Fish and Wildlife Service, Division of Economics, Arlington.

[13] U.S. Fish and Wildlife Service (USFWS) (2006) Economic Effects of Rainbow Trout Production by the National Fish Hatchery System. USFWS, Atlanta.

[14] Barnes, M.E. (2007) Fish Hatcheries and Stocking Practices: Past and Present. In: Berry, C., Higgins, K., Willis, D. and Chipps, S., Eds., History of Fisheries and Fishing in South Dakota, South Dakota Department of Game, Fish and Parks, Pierre, 267-294.

[15] South Dakota Department of Game, Fish and Parks (SDGFP) (2018) Final Performance Report. F16AF00525/F-41-D-27, Pierre.

[16] South Dakota Department of Game, Fish and Parks (SDGFP) (2015) Strategic Plan 2016-2020, Pierre. https://gfp.sd.gov/userdocs/docs/strategic-plan-2.pdf

[17] South Dakota Department of Game, Fish and Parks (SDGFP) (2019) Division of Wildlife Budget Information, Pierre. https://gfp.sd.gov/budget

[18] Bureau of Labor Statistics (BLS) (2018) Bureau of Labor Statistics. https://doi.org/10.4135/9781412963947.n46

[19] Dalton, R.S., Bastian, C.T., Jacobs, J.J. and Wesche, T.A. (1998) Estimating the Economic Value of Improved Trout Fishing on Wyoming Streams. North American Journal of Fisheries Management, 18, 786-797. https://doi.org/10.1577/1548-8675(1998)018<0786:ETEVOI >2.0.CO;2

[20] Whitehead, J.C. and Aiken, R. (2007) Temporal Reliability of Willingness to Pay from the National Survey of Fishing, Hunting and Wildlife-Associated Recreation. Applied Economics, 39, 777-786. https://doi.org/10.1080/00036840500438996

[21] Johnson, D.M., Behnke, R.J., Harpman, D.V. and Walsh, R.G. (1995) Economic Benefits and Costs of Stocking Catchable Rainbow Trout: A Synthesis of Economic Analysis in Colorado. North American Journal of Fisheries Management, 15, 26-32. https://doi.org/10.1577/1548-8675(1995)015<0026:EBACOS>2.3.CO;2

[22] Barnes, M.E., Simpson, G. and Durben, D.J. (2009) Post-Stocking Harvest of Catchable-Sized Rainbow Trout Enhanced by Dietary Supplementation with a Fully Fermented Commercial Yeast Culture during Hatchery Rearing. North American Journal of Fisheries Management, 29, 1287-1295. https://doi.org/10.1577/M08-218.1

[23] Johnson, B., Lott, J., Nelson-Stastny, W. and Riis, J. (1997) Annual Fish Population and Sport Fish Harvest Surveys on Lake Oahe, South Dakota 1996. Annual Report 97-15, South Dakota Department of Game, Fish and Parks, Pierre.

[24] U.S. Fish and Wildlife Service and U.S. Census Bureau (USFWS and USBC) (1997) 1996 National Survey of Fishing, Hunting, and Wildlife-Associated Recreation. Washington DC. https://doi.org/10.3886/ICPSR34641

[25] American Sportfishing Association (ASA) (2007) State and National Economic Effects of Fishing, Hunting and Wildlife-Related Recreation on U.S. Forest Service-Managed Lands. https://doi.org/10.3886/ICPSR34641

[26] U.S. Fish and Wildlife Service (USFWS) (2001) Economic Effects of Trout Production by National Fish Hatcheries in the Southeast. USFWS, Atlanta.

[27] Charbonneau, J.J. and Caudill, J. (2010) Conserving America's Fisheries. An Assessment of Economic Contributions from Fisheries and Aquatic Resource Conservation. U.S. Fish and Wildlife Service, Division of Economics, Arlington. https://www.fws.gov/home/feature/2011/pdf/fisherieseconomicreport.pdf

[28] Tourism Economics (2017) Economic Impact of Tourism in South Dakota, 2017. 
https://sdvisit.com/sites/default/files/2018-06/17EcoImp_Tourism_Economics.pdf

[29] Griliches, Z. (1979) Issues in Assessing the Contribution of Research and Development to Productivity Growth. Bell Journal of Economics, 10, 92-116. https://doi.org/10.2307/3003321

[30] Williams, D. and Rank, A.D. (1998) Measuring the Economic Benefits of Research and Development: The Current State of the Art. Research Evaluation, 7, 17-30. https://doi.org/10.1093/rev/7.1.17

[31] Bessette, R.W. (2003) Measuring the Economic Impact of University-Based Research. Journal of Technology Transfer, 28, 355-361. https://doi.org/10.1023/A:1024917601088

[32] Evenson, R.E. (2001) Economic Impacts of Agricultural Research and Extension. In: Gardner, B.L. and Rausser, G.C., Eds., Handbook of Agricultural Economics, Vol. 1, Elsevier, Amsterdam, 573-628. https://doi.org/10.1016/S1574-0072(01)10014-9

[33] Salter, A.J. and Martin, B.R. (2001) The Economic Benefits of Publicly Funded Basic Research: A Critical Review. Research Policy, 30, 509-532. https://doi.org/10.1016/S0048-7333(00)00091-3

[34] Blanco, L.R., Gu, J. and Prieger, J.E. (2016) The Impact of Research and Development on Economic Growth and Productivity in the US States. Southern Economic Journal, 82, 914-934. https://doi.org/10.1002/soej.12107 